\title{
Strategi Terapiutik Korban Homoseks: Studi Terhadap Pemikiran Ibnu Qayyim al-Jauziyah
}

\author{
Aswar \\ STKIP Muhammadiyah Barru \\ aswar093010@gmail.com \\ Mukran H. Usman \\ Sekolah Tinggi Ilmu Islam dan Bahasa Arab (STIBA) Makassar \\ mukran@stiba.ac.id \\ Azwar Iskandar \\ Sekolah Tinggi Ilmu Islam dan Bahasa Arab (STIBA) Makassar \\ azwar@stiba.ac.id
}

\begin{abstract}
This study aims to find the therapeutic strategies to the gay victims. The phenomenon of the rising of the gay community is increasingly worrying, of course that behavior is abnormal for Indonesians, especially for Muslims. This community actually began to grow in 1982 in Solo, 1985 in Yogyakarta, 1993 in Pekanbaru, 1999 in Surabaya, and still exists in cyberspace (social media). The research method applied is a qualitative approach with the type of composed hermeneutics research analysis, with the object study of therapeutic thought of Ibn Qayyim al-Jauziyah and the examined subject in the RSC-M Malang (Ruqyah Syar'iyyah Center Malang). The study found four therapeutic strategies that can be applied to the gay victims. First, the main focus of intervention is in mind/belief intervention. Second, the target towards an ideal person is the transfer from a sinful person to a person who obeys God's commandments and avoids His prohibition. Third, analysis and diagnosis is efforts to identify and find the errors in the chain of perception, belief, sex drive, behavior, and habit of the gay victims. Fourth, the application of homosexual victim alleviation techniques consists of prevention and healing pathways, prevention pathways is in the form of 'self-training' subjecting themselves to the same things, while healing pathways is in the form of the application of intervention techniques of the mind, self-conversion and statements of repentance and istigfar, as well as the worship therapy. The
\end{abstract}


recommendations of this study is to be applied by practitioners and counsellors in providing counselling services to the gay victims.

Keywords: Homosexual Victims, Ibnu Qayyim al-Jauziyah, Therapeutic.

\begin{abstract}
Abstrak
Penelitian ini bertujuan untuk menemukan strategi terapiutik pada korban homoseks. Fenomena bermunculannya komunitas homoseks semakin mengkhawatirkan, tentunya perilaku tersebut adalah abnormal bagi masyarakat Indonesia, terutama pemeluk Islam. Komunitas tersebut sejatinya mulai tumbuh pada tahun 1982 di Solo, tahun 1985 di Yogyakarta, tahun 1993 di Pekanbaru, tahun 1999 di Surabaya hingga saat ini masih tetap eksis di dunia maya (medsos). Metode penelitian yang diaplikasikan adalah pendekatan kualitatif dengan tipe riset analisis hermeneutika bersusun, dengan objek kajian pemikiran terapiutik Ibnu Qayyim Al-Jauziyah dan subjek terteliti pada komunitas RSC-M Malang (Ruqyah Syar'iyyah Center Malang). Adapun hasil penelitian ditemukan empat strategi terapiutik yang dapat diterapkan pada korban homoseks. Di antaranya adalah: pertama, fokus utama pengintervensian, berfokus pada intervensi pikiran/keyakinan; kedua, target menuju pribadi ideal, pengalihan dari pribadi yang senang berbuat dosa dan maksiat menuju pribadi yang taat kepada perintah Allah dan menjauhi larangan-Nya; ketiga, analisis dan diagnosis, upaya mengidentifikasi dan menemukan kesalahan dalam rantai persepsi, keyakinan, sex drive, behavior, dan habit korban homoseks. Keempat, penerapan teknik pengentasan korban homoseks terdiri dari jalur pencegahan dan penyembuhan, jalur pencegahan berupa 'latih diri' menundukkan pandangan dan menyibukkan diri dengan perkaraperkara yang maslahat, sementara jalur penyembuhan berupa penerapan teknik intervensi pikiran, muhasabah diri dan pernyataan tobat dan istigfar, serta terapi ibadah. Rekomendasi dari penelitian ini ialah untuk diterapkan oleh praktisi helping profession dan konselor dalam pemberian layanan konseling terhadap korban homoseks.
\end{abstract}

Kata Kunci: Ibnu Qayyim al-Jauziyah, Korban Homoseks, Terapiutik.

\title{
Pendahuluan
}

Eksistensi pergumulan kaum homoseks telah tampak di sejumlah Kota besar di Indonesia dalam dua dekade terakhir ini. Hal itu ditandai dengan berdirinya sejumlah organisasi yang mewadahi kepentingan kaum homoseks. Rosyidah mengatakan bahwa awal mula berdirinya organisasi Lesbian, Gay, Biseksual, dan Transgender (LGBT) di Indonesia pada tahun 1982 dengan 
organisasi bernama Lambda Indonesia di Kota Solo, kemudian terbentuk Indonesian Gay Society (IGS) pada tahun 1985 di Kota Yogyakarta, dan pada tahun 1992-1993 organisasi gay berdiri di Kota Pekanbaru, Bandung, Denpasar dan Malang, hingga pada tahun 1999 komunitas LGBT dari seluruh kota di Indonesia mengadakan Gay Pride di kota Surabaya ${ }^{1}$. Bahkan, akhir-akhir ini, pada tanggal 04 Juni 2019 pihak Google Doodle secara fulgar menyajikan animasi spesial bertajuk "Celebrating 50 Years of Pride" yang ditujukan untuk perayaan komunitas LGBT, sehingga banyak influencer Indonesia yang turut menyiarkannya di media sosial semisal Instagram TV ${ }^{2}$.

Adapun lembaga yang masih eksis hingga hari ini dan mewadahi nilainilai kesetaraan serta penghormatan terhadap kaum LGBT ialah organisasi Arus Pelangi, yang berdiri sejak tahun $2006^{3}$. Sementara itu, Arus Pelangi juga eksis di dunia maya (media sosial), yang dapat ditemukan pada akun Youtube, Instagram, Facebook, dan Twitter, serta aplikasi Soundcloud-nya ${ }^{4}$. Dari sisi jumlah populasi kaum LGBT, Hasnah dan Alang menambahkan bahwa Indonesia menempati peringkat kelima terbesar di dunia, dengan populasi sebanyak tiga persen dari jumlah penduduk Indonesia, artinya dari seratus orang dalam suatu pertemuan, memungkinkan tiga di antaranya adalah $\mathrm{LGBT}^{5}$.

Dari sisi kesehatan, pengidap penyakit HIV/AIDS banyak berasal dari kaum LGBT. Nugrohowati, dkk., memaparkan bahwa pada tahun 2015 jumlah kasus HIV kurang lebih terdapat 180 ribu kasus, dan meningkat pada tahun 2016 menjadi kurang lebih 786 ribu kasus ${ }^{6}$. Atas fakta sosial tersebut, Riswanto dan Aswar melalui penelitiannya menyebutkan bahwa proses habituasi, faktor lingkungan, teman sebaya, dan gaya hidup adalah pemicu eksistensi perilaku

${ }^{1}$ K Rosyidah, S., "Pengaruh Globalisasi Dalam Perkembangan Perjuangan Identitas Dan Hak Kelompok LGBT Di Indonesia," Global Dan Policy 5, no. 2 (2017): 183-98, http://ejournal.upnjatim.ac.id/index.php/jgp/article/view/1892.

${ }^{2}$ M Giri, A., A Bajari, and E Maryani, "LGBT Di Era Digital: Eksistensi Dan Kontroversi," in Book Chapter: Communication \& Information Beyond Boundaries (Bandung: Seminar Nasional MACOM III Universitas Padjadjaran 2019, 2019), 93-100.

3 The SMERU Research Institute, "Arus Pelangi," 2020, http://smeru.or.id/id/content/arus-pelangi\#: :text=Arus Pelangi adalah sebuah organisasi,LGBT) sebagai hak asasi manusia.

${ }^{4}$ Arus Pelangi, “Arus Pelangi," 2020, http://www.aruspelangi.or.id/.

${ }^{5} \mathrm{H}$ Hasnah and S Alang, "Lesbian, Gay, Biseksual Dan Transgender (Lgbt) Versus Kesehata: Studi Etnografi," Jurnal Kesehatan 12, no. 1 (2019): 63-72, https://doi.org/10.24252/kesehatan.v12i1.9219.

${ }^{6}$ Nunuk Nugrohowati et al., "Factors Associated with Risky Behavior for HIV/AIDS Transmission Among Youth Organization in Depok, West Java," in Proceedings of the 4th International Symposium on Health Research (ISHR 2019), vol. 22 (Paris, France: Atlantis Press, 2020), 648-54, https://doi.org/10.2991/ahsr.k.200215.127. 
LGBT seseorang ${ }^{7}$. Tentunya, fenomena ini juga adalah gejala patologi sosial, dan bukanlah sesuatu yang normal serta sangat mengkhawatirkan ${ }^{8}$. Belum lagi dari perspektif agama, ajaran Islam sebagai agama mayoritas yang dianut oleh masyarakat Indonesia, sangat melarang perilaku homoseksual tersebut. Mansur menyebutkan bahwa meskipun perilaku homokseksual sangat dilarang dalam ajaran Islam, namun pelaku/korban homoseksual dapat dimaafkan tatkala mereka mau bertobat dengan jujur dan kembali menjadi manusia normal'. Dengan demikian, kaum homoseksual memungkinkan untuk dapat dibimbing dan diterapi menuju fitrahnya, sebagaimana Islam memandang bahwa setiap manusia terlahir dalam keadaan fitrah (suci), atau normal secara psikologis. Untuk itu, diperlukan sebuah konsep terapiutik dalam mengentaskan perilaku malasuai tersebut.

Dalam Islam, protokol terapi kaum homoseks tampak tersirat dari sumber utamanya yakni Al-Qur'an dan hadis-hadis Nabi saw. Namun, protokol tersebut dapat dicari-temukan pada konsep pemikiran terapiutik ulama klasik dan juga praktisi terapi Islami. Ibnu Qayyim Al-Jauziyah adalah seorang ulama yang cukup kredibel dalam membahas terapi hati yang ditunjukkan dalam karyakaryanya. Salah satunya Fathuddin mengatakan bahwa karya ihwal ilmu Tazkiyatun Nafs (terapi hati) beliau dapat ditemukan di Madarij As-Salikin ${ }^{10}$. Begitu pun dalam kitab-kitab beliau seperti Ad-daa' wa ad-Dawaau', Fawaa-idul Fawaa-id, Ighatsatul Labfan, dan lain sebagainya adalah kitab yang sarat akan muatan ilmu Tåkiyatun Nafs (terapi hati).

Sehubungan dengannya, telah ditemukan oleh penulis bahwa komunitas Ruquah Syariyyah Center Malang (RSC-M Malang) adalah merupakan sebuah kumpulan terapis Islam yang mengaplikasikan konsep pemikiran terapiutik beliau di lapangan dalam menangani korban homoseks. Untuk itu, penulis berinisiatif melakukan penelitian ihwal integrasi strategi terapiutik pada teks pemikiran Ibnu Qayyim Al-Jauziyah dan komunitas RSC-M Malang, kaitannya dalam pengentasan korban homoseks.

Sebelumnya, sejumlah penelitian relevan telah dilakukan oleh para praktisi psikologi Islam dan pendidikan Islam terkait perilaku homoseksual. Di

${ }^{7}$ Dody Riswanto and Aswar Aswar, "Prosedur Konseling Rational Emotive Behavior Dalam Penanganan Pelaku LGBT," Advice: Jurnal Bimbingan Dan Konseling 2, no. 1 (June 15, 2020): 12-27, https://doi.org/10.32585/advice.v2i1.682.

8 Nugrohowati et al., "Factors Associated with Risky Behavior for HIV/AIDS Transmission Among Youth Organization in Depok, West Java."

9 S Mansur, "Homoseksual Dalam Perspektif Agama-Agama Di Indonesia," Aqlania 8, no. 1 (2017): 21-60, https://doi.org/http://dx.doi.org/10.32678/aqlania.v8i01.1020.

${ }^{10} \mathrm{H}$ Fathuddin, M. and R Amir, F., "Konsep Tazkiyatun Nafs Menurut Ibnu Qoyyim Al Jauziyah Dalam Kitab Madarijus Shalikin Serta Implikasinya Terhadap Pendidikan," TADBIR MUWAHHID 5, no. 2 (2016): https://doi.org/http://dx.doi.org/10.30997/jtm.v5i2.332. 
antaranya, Khairani \& Saefudin melalui pengkajianya ihwal pandangan psikologi Islam terhadap homoseksual, dan ditemukan deskripsi bahwa perbuatan homoseksual bertentangan dengan fitrah manusia sebagai makhluk ciptaan Allah, dan merupakan perbuatan yang melampaui batas ${ }^{11}$. Alamsyah, dkk., pada penelitiannya perihal pendidikan agama Islam dalam mengatasi perilaku gay, ditemukan bahwa pelaku/korban homoseks dapat diberikan bimbingan dan konseling Islam dengan cara ruqyah syar'iyyah dan ritual riyadhah ibadah ${ }^{12}$. Agaknya, kedua penelitian tersebut sejalan dengan penelitian penulis, namun hanya berkisar pada tataran konsep dan penawaran intervensi, belum pada tataran praktik di lapangan.

Dengan proyeksi kebaruan, penelitian ini berupaya mencari-temukan konsep terapiutik pemikiran Ibnu Qayyim Al-Jauziyah yang hidup di lapangan melalui praktik terapi Islami komunitas RSCM-Malang, kaitannya dengan strategi terapiutik terhadap korban homoseks. Oleh karena itu, penelitian ini bertujuan untuk menemukan strategi terapiutik pada korban homoseks.

Penelitian ini menggunakan pendekatan kualitatif dengan tipe riset analisis hermeneutika bersusun (AHB). Tipe riset ini berkenaan dengan penelitian terhadap fenomena dan noumenon serta mengenai teks merujuk pada strategi penafsiran atas penafsiran (refleksif), yang sifatnya multiple interpretation, menjangkau penafsiran tingkat tiga (triple hermeneutics) atau tingkat empat (quadri hermeneutics) ${ }^{13}$. Inti dari refleksivitas ialah mengarahkan minat pada cara kita mengkontruksi diri sendiri secara sosial, relasional, dan menekankan pada perluasan languages of understanding, the interpretation of interpreting subjects 'Ala Giddens, sambil juga mengkonstruksi objek ('di luar sana') dalam penelitian ${ }^{14}$. Mappiare mengimbuhkan bahwa riset hermeneutika pada asalnya merupakan penelitian terhadap teks, namun pengertian teks mengalami perluasan cakupan berupa kata-kata dan simbol, tindakan, aksi, suasana pedesaan, dan selainnya, yang semua itu bersangkut paut pada kesadaran atau interpretasi manusia sebagai aktor atau agen yang aktif terlibat di dalamnya ${ }^{15}$.

11 A Khairani and D Saefudin, "Homoseksual Berdasarkan Pandangan Psikologi Islam,"

Ta'dibuna: Jurnal Pendidikan Islam 7, no. 2 (2018): 114-36, https://doi.org/10.32832/tadibuna.v7i2.1356.

12 Agung Alamsyah, Hasbiyallah Hasbiyallah, and Nanat Fatah Natsir, "Pendidikan Agama Islam Dalam Mengatasi Perilaku Homoseksual (Gay)," Risâlah, Jurnal Pendidikan Dan

Studi Islam 6, no. 1 (October 15, 2019): 139-49, https://doi.org/10.31943/jurnal_risalah.v6i1.117.

13 Andi Mappiare-AT, "Tipe-Tipe Metode Riset Kualitatif Untuk Eksplanasi Sosial Budaya Dan Bimbingan Konseling” (Malang: Elang Mas bersama Prodi Bimbingan dan Konseling Fakultas Ilmu Pendidikan Universitas Negeri Malang, 2013). (Sage, 2017).

${ }^{14}$ M. Alvesson and K. Sköldberg, Reflexive Methodology: New Vistas for Qualitative Research

15 Mappiare-AT, “Tipe-Tipe Metode Riset Kualitatif Untuk Eksplanasi Sosial Budaya Dan Bimbingan Konseling." 
Berkenaan penafsiran refleksif pada penelitian ini, pada tingkat satu adalah teks pemikiran terapiutik Ibnu Qayyim Al-Jauziyah, pada tingkat dua adalah teks subjek terteliti dalam komunitas RSC-M Malang, pada tingkat tiga adalah interpretasi terhadap kedua teks tersebut, dan pada tingkat empat adalah interpretasi meta-teori dan kritik penulis. Untuk menguji keabsahan data, penulis menerapkan triangulasi sumber data, peer review dan validitas intersubjektivitas ${ }^{16}$, antara pemakai pemikiran Ibnu Qayyim Al-Jauziyah dan ahli bimbingan dan konseling. Hal tersebut dilakukan guna memperoleh hakikat pemaknaan dan kesimpulan hasil penelitian yang dapat dipertanggungjawabkan.

Adapun guna mengekstensifkan pola pemahaman terhadap penelitian, maka digunakan sistem pengkodean data, secara sederhana ditampilkan pada tabel 1 dan tabel 2 berikut:

\section{Tabel 1. Sistem Pengkodean \\ Teks Pemikiran Ibnu Qayyim Al-Jauziyah}

\begin{tabular}{cccc}
\hline $\begin{array}{c}\text { Objek } \\
\text { Penelitian }\end{array}$ & Nama Kitab & Pengkodean & Keterangan \\
\hline $\begin{array}{c}\text { Ibnu } \\
\text { Qayyim Al- } \\
\text { Jauziyah }\end{array}$ & Fawaidul Fawaid & FF/h.507 & FF: Nama Kitab \\
& & & h.507: Halaman 507 \\
\hline
\end{tabular}

Tabel 2. Sistem Pengkodean Teks Subjek terteliti Lapangan

\begin{tabular}{cccc}
\hline $\begin{array}{c}\text { Subjek } \\
\text { Penelitian }\end{array}$ & $\begin{array}{c}\text { Tanggal } \\
\text { Wawancara }\end{array}$ & Pengkodean & Keterangan \\
\hline Ahmad & AF $/ 29 / 02 / 2015$ & AF $/ 29 / 02 / 2015$ & AF: Inisial nama \\
Fulan & & & 29/02/2015: \\
& & & tanggal/bulan $/$ tahun \\
\hline
\end{tabular}

\section{Hasil dan Pembahasan}

Pada penelitian ini ditemukan empat strategi terapiutik terhadap korban homoseks yaitu dimulai pada: pertama, fokus utama pengintervensian, yang mana memfokus pada "pikiran" seseorang, dari pola pikir negatif atau buruk ditujukan ke pola pikir berorientasi Allah dan hari akhirat. Kemudian, kedua, target menuju pribadi ideal ialah "proses peralihan" dari pribadi yang tidak sehat menuju pribadi sehat, seperti dari keragu-raguan menuju kepada keyakinan, dari kebodohan menuju kepada ilmu, dari lalai menuju kepada ingat, dari khianat menuju kepada taubat, dari kepongahan menuju kepada ikhlas, dari dusta

16 Andi Mappiare-AT, Dasar-Dasar Metodologi Riset Kualitatif Untuk Ilmu Sosial Dan Profesi (Malang: Jenggala Pustaka Utama Bersama Fakultas Ilmu Pendidikan Universitas Negeri Malang, 2009). 
menuju kepada jujur, dari kelemahan menuju kepada ketegaran, dari ujub menuju kepada ketundukan, dari kesombongan menuju kepada tawaduk, dari kelengahan menuju kepada amal.

Ketiga, analisis dan diagnosis ditemukan mata rantai pengamatan perilaku yakni diawali dari pandangan ke bisikan hati dan pikiran, yang kemudian itu menghasilkan ide-ide. Lalu, ide-ide itu memunculkan kehendak, selanjutnya, kehendak itu melahirkan perbuatan, dan perbuatan yang dilakukan berulang kali itulah yang kemudian menjadi tradisi/kebiasaan berperilaku. Interpretasinya kemudian membentuk akronim PsiKiS-BH, yakni persepsi, keyakinan, sex drive, behavior, dan habit.

Keempat, penerapan teknik pengentasan korban homoseks terdapat dua cara berupa pencegahan dan penyembuhan. Cara pencegahan ditempuh melalui 'latih diri' menundukkan pandangan dan menyibukkan diri kepada hal-hal yang maslahat. Sementara cara penyembuhan ditempuh melalui penerapan teknik intervensi pikiran, muhasabah diri, pernyataan tobat dan istigfar dan terapi ibadah. Adapun terapi ibadah meliputi doa mustajabah, zikir pagi-petang, puasa, salat, sedekah/zakat, tadabbur al-Qur'an, iktikaf, dan rukiah ilahiah.

\section{Fokus Utama Pengintervensian}

Ibnu Qayyim Al-Jauziyah mengemukakan bahwa "Kebaikan dan keburukan itu bersumber dari pikiran, karena pikiran adalah tempat bermulanya kehendak dan keinginan untuk bersikap zuhud dan meninggalkan sesuatu, atau mencintai maupun membenci sesuatu" (FF/h.507) ${ }^{17}$. Selanjutnya, Ibnu Qayyim Al-Jauziyah menyatakan bahwa "Pikiran yang paling mulia dan paling bermanfaat adalah yang ditujukan untuk Allah dan negeri akhirat" (AWA/h. 356 ${ }^{18}$. Berkenaan pola pikir berorientasi Allah dan hari akhirat sebagai sasaran intervensi pengubahan perilaku ditemukan pula oleh penulis di lapangan subjek terteliti AF di Masjid Qolbun Salim Malang berpendapat bahwa "Seluruh fisike (tindakan) dan perasaan itu merupakan produk dari cara berpikir, jadi sehatnya jiwa dan rohani itu dipengarubi oleh pola pikir manusia sendir" (AF/29/02/2015). AF dengan pernyataan serupa-selaras juga bertutur di lain kesempatan bahwa "Segenap perasaan seseorang itu dipengarubi oleh pikiran, dan obat cara berpikir yaitu berikan bake langit' (AF/06/09/2015).

Paparan di atas menyiratkan bahwa cara atau pola berpikir dapat mempengaruhi segenap perasaan dan perilaku, dan berimplikasi pada kesehatan mental seseorang. Adapun cara intervensi pengubahan perilaku, rasa-rasanya yang paling efektif adalah berupa pengubahan cara berpikir seseorang dalam

${ }^{17}$ I.Q. Al-Jauziyah, Fawaa-Idul Fawaa-Id, ed. S Terjemahan Djamaluddin (Jakarta: Pustaka Imam Asy-Syafi'i, 2012).

18 I.Q. Al-Jauziyah, Ad-Daa' Wa Ad-Dawaau', ed. A Terjemahan Kurniawan, Jakarta (Pustaka Imam Asy-Syafi'i, 2009). 
memenuhi hak/ketentuan yang berasal dari atas langit. Maksud tersebut, alurnya dipahami sebagai cara berpikir yang berlandaskan pada hak dan/atau ketentuan Allah yang berada di atas langit, Yang Maha Tinggi. Barangkali ini pulalah yang dimaksud sebagai pola pikir berorientasi akhirat, dalam mana Allah-lah yang menguasai hari pembalasan, Yang Maha Kuasa atas segala sesuatu.

Kedua kutipan pernyataan tersebut dapat diinterpretasikan bahwa prosedur dasar yang mesti dilakukan dalam intervensi konseling adalah pengubahan pola pikir/keyakinan, berlandaskan pada hak/ketentuan Allah. Dari pola pikir tersebut, tentu dapat mempengaruhi perasaan dan perilaku seseorang. Bila ditarik ke dalam konseling, dicermati, maka gayut dengan teori REBT (Rational Emotive Behavior Therapy), dalam mana dipaparkan oleh Ellis \& Dryden bahwa REBT theory, people have almost innumerable Beliefs (B's)—cognitions, thoughts, or ideas - about their Activating events (Afc); and these B's importantly exert strong influences on their cognitive, emotional, and behavioral Consequences $\left(C^{\prime} s\right)^{19}$. Maksud dari pernyataan tersebut kurang lebih bahwa teori REBT adalah keyakinan seseorang yang sudah barangtentu berkutat pada (B) kognisi, pikiran, atau ide-ide berkenaan dengan situasi pengaktifnya (A), dan B (keyakinan) ini berperan penting dalam mendorong daya, berpengaruh kuat pada konsekuensi kognitif, emosi, dan tindakan (C). Corey mengkonkretkan skema ABC dalam pendekatan REBT tersebut pada bentuk diagam berikut ini: ${ }^{20}$

\section{$\mathrm{A}$ (activating event $) \leftarrow \mathrm{B}$ (belief) $\rightarrow \mathrm{C}$ (emotional and behavioral consequence) $\uparrow$ \\ $\mathrm{D}$ (disputing intervention) $\rightarrow \mathrm{E}$ (effect) $\rightarrow \mathrm{F}$ (new feeling)}

Dari skema di atas semakin tampak jelas bahwa keyakinan, dalam mana berkutat pada kognisi, pikiran, dan ide-ide dapat berfungsi 'eksekutif antara $\mathrm{A}$ (peristiwa/situasi yang mengatifkan) dan C (konsekuensi emosi dan tindakan). Dengan demikian, dari ulasan-ulasan sebelumnya, maka dapat disimpulkan bahwa teks pemikiran Ibnu Qayyim Al-Jauziyah berkenaan dengan pikiran/keyakinan dapat memengaruhi perasaan dan tindakan seseorang, relevan dengan kerangka bangun pendekatan REBT. Oleh karena itu, pemikiran terapiutik Ibnu Qayyim Al-Jauziyah dapat pula diaplikasikan bimbingan dan konseling.

\section{Target Menuju Pribadi Ideal}

Setelah mengabstraksi gambaran fokus utama pengintervensian, maka perlu dipahami secara sederhana 'proses peralihan' dari pribadi bermasalah menjadi pribadi sehat. Oleh karena itu, maka diperlukan sekelumit pengetahuan

19 A Ellis and W Dryden, The Practice of Rational Emotive Behavior Therapy (New York: Springer Publishing Company, Inc, 2007).

20 G. Corey, Theory and Practice of Counseling and Psychotheraphy, Ninth Edition (USA: Thomson Brooks/Cole, 2013). 
umum ihwal ciri pribadi sehat. Ibnu Qayyim Al-Jauziyah mengatakan bahwa "Jika jiwa merasa tentram dari keragu-raguan kepada keyakinan, dari kebodohan kepada ilmu, dari lalai kepada ingat, dari khianat kepada taubat, dari kepongahan kepada ikhlas, dari dusta kepada jujur, dari kelemahan kepada ketegaran, dari ujub kepada ketundukan, dari kesombongan kepada tawaduk, dari kelengahan kepada amal, berarti roh thuma'ninah yang menyusup" (AR/h.362) ${ }^{21}$. Segayut dengan ini, penulis dengan iseng-isengnya menggali pendapat seorang roqy berinisial TG di pelataran Masjid Abu Dzar Al-Ghifari, dan berkata, "Pribadi sehat, yaa... pribadi yang senantiasa bertakwa, menjaubi larangan dan menjalankan perintah Allah, itu to.." (TG/03/12/2012).

Dari sitatan di atas, terjadi suatu penyimpulan interpretasi yang dinyatakan oleh TG, yang mana agak berbeda dari penjabaran ciri pribadi sehat dari Ibnu Qayyim al-Jauziyah. TG dinilai cukup memahami bahwa pribadi sehat sebatas pada pribadi yang senantiasa bertakwa, menjauhi larangan dan menjalankan perintah Allah, tanpa ada penjabaran lebih rinci selanjutnya. Sementara Ibnu Qayyim Al-Jauziyah merincikan sifat buruk (pribadi sehat) dan sifat baik (pribadi sehat).

Pribadi sehat, berkenaan dengan keyakinan, dalam konsepsi REBT, Dryden mengatakan bahwa "in REBT, beliefs are rational or healthy if they meet three criteria: they are true, they are logical, they have healthy consequences." 22 Pernyataan ini, terkesan masih global, relatif, dan belum tampak arah-tujuan yang jelas, perihal patokan keyakinan. Adapun pada pernyataan Ibnu Qayyim Al-Jauziyah dan subjek terteliti TG, pribadi sehat sebagai tujuan atas diadakannya teknik pengubahan perilaku berkisar pada beberapa hal. Secara umum, pribadi sehat adalah pribadi yang bertakwa. Adapun secara khusus, pribadi sehat adalah pribadi yang bertauhid, berilmu, berzikir (mengingat Allah), bertaubat, ikhlas, jujur, tegar (asertif), tunduk pada ketentuan Allah, tawaduk, dan senang beramal saleh. Keseluruhan ciri pribadi sehat tersebut, sudah tentu dipandang sebagai tujuan dari diadakannya intervensi pengubahan perilaku kepada korban homoseks.

\section{Analisis dan Diagnosis Terapiutik}

Ihwal analisis dan diagnosis terapiutik, Ibnu Qayyim Al-Jauziyah mengemukakan bahwa "Pengobatan... membutuhkan analisa dan diagnosa" (TN/h.7). ${ }^{23}$ Dari tinjauan lapangan juga ditemukan bahwa subjek terteliti AF di Masjid Qolbun Salim Malang, bertutur, "Setiap orang penyakitnya itu berbeda-beda,

${ }^{21}$ I.Q. Al-Jauziyah, Ar-Rub Li Ibnul Qayyim, ed. Terjemahan Suhardi (Jakarta: Pustaka AlKautsar, 2012). 2011).

${ }^{22}$ W Dryden, Understanding Psychological Health: The REBT Perspective (USA: Routledge,

${ }^{23}$ I.Q. Al-Jauziyah, Thibbun Nabawi, ed. A. U. B. Terjemahan Al-Maidani (Bandung: Penerbit Jabal Pustaka, 2015). 
dan juga dari pencetus yang berbeda-beda" (AF/26/10/2015). Kedua pernyataan tersebut mengindikasikan arah pemikiran yang semakna, dalam mana dibutuhkan analisis dan diagnosis sebagai prosedur awal intervensi pengubahan perilaku. Oleh karena itu, setiap korban homoseks sejatinya memiliki problem psikologis yang berbeda-beda, dan dipicu pula oleh beraneka ragam faktor penyebab, pada sejumlah rentetan permasalahannya.

Pada domain analisis dan diagnosis penggalian masalah, dalam konsepsi REBT, Corey menyatakan bahwa "through the therapeutic process, clients learn skills that give them the tools to identify and dispute irrational beliefs that have been acquired."24 Tampaknya konsep ini hanya memokus pada upaya identifikasi pikiran/keyakinan irasional, bersifat umum pada kedua belas indikatornya, dalam mana mencerminkan prosesi analisis dan diagnosis pribadi bermasalah tanpa melihat kekhasan latar atau konstruk budaya seseorang, utamanya pemeluk Islam (muslim).

Selanjutnya, alur dan pemetaan analisis dan diagnosis terapiutik dibahasakan oleh Ibnu Qayyim al-Jauziyah bahwa "cikal bakal setiap pengetahuan dan perbuatan adalah bisikan hati dan pikiran. Bisikan hati dan pikiran itu kemudian menghasilkan ide-ide. Lalu, ide-ide itu memunculkan kehendak, selanjutnya, kehendak itu melahirkan perbuatan, lantas, perbuatan yang dilakukan berulang-ulang itulah yang kemudian menjadi tradisi" $(\mathrm{FF} / \mathrm{h} .391)^{25}$. Subjek terteliti AF juga memahami bahwa "Proses terbentuknya perilaku seseorang itu dimulai dari pandangan.. ke lintasan pikiran. menjadi pikiran atau ide.. jadi syahwat atau selera. kehendak.. lalu tekad.. trus perbuatan.. dan akbirnya menjadi kebiasaan" (AF/09-02-2016). Kedua pernyataan ini menyiratkan akan proses pembentukan perilaku seseorang yang berawal dari pikiran/keyakinan dan pandangan (persepsi). Lalu berikutnya akan menimbulkan lintasan-lintasan pikiran, menstimuli nafsu-syahwat, dan berujung pada suatu tindakan, serta terhabituasi dan mengkristal menjadi suatu kebiasaan (habit).

Adapun AF kembali merincikan ihwal aspek-aspek yang dianalisis pada pribadi bermasalah, beliau bertutur bahwa "Aspek-aspek yang dianalisa.. yaa.. bisa memaknai baik dan buruk.. masalah benar-salah. masalah mulia-bina, ada aspek nafsu. yang di dalam nafsu itu (ada cinta. rindu. marah).. aspek hati (ada salim, mayyit, maridh).. trus ada aspek perilaku. ada aspek bagaimana setan memperdaya manusia.. jadi menganalisa ketergelinciran seseorang. perubahan perilaku seseorang.. sebab kalo Islam itu musub ada dua, ada nafsu, ada setan.. ada lagi anu itu. aspek sejarah.. histori.. untuk diambil pelajaran.. ibrah.." Sitatan ini menyiratkan bahwa sejatinya terdapat banyak aspek yang dapat dicermati dalam mengidentifikasi permasalahan korban homoseks, dalam mana tiap-tiap aspek memiliki keterhubungan satu sama lain, dan semua dikembalikan pada standar atau kacamata syariat.

\footnotetext{
${ }^{24}$ Corey, Theory and Practice of Counseling and Psychotheraphy, Ninth Edition.

25 Al-Jauziyah, Fawaa-Idul Fawaa-Id.
} 


\section{Praktik Analisis dan Diagnosis Terapiutik pada Komunitas RSC-M Malang}

TG adalah salah seorang roqy (terapis Islam) dalam komunitas RSC-M. TG pernah menangani kasus homoseks (lesbi) di sela-sela kesibukannya sebagai seorang pengusaha dan Dosen Psikologi di salah satu Universitas Swasta di Kota Malang. Kasus homoseks pernah ditangani oleh TG pada seorang lesbi, dalam mana tuturannya, "Kasus lesbi ini adalab salah seorang mahasiswi universitas tertentu di kota Malang.. inisialnya.. anggap saja 'Bunga'.. dia itu awalnya merasa baik-baik saja.. masib ada ketertarikean kepada lawan jenis.. namun seiring berjalannya wak.tu.. nggak ada laki-laki yang suka sama dia.. padahal si wanita ini sudah melakukan sejumlah perawatanperawatan. (TG/12-03-2016)." Sitatan ini menunjukkan bahwa 'Bunga' mengalami frustasi.

Berangkat dari rasa frustasi yang berlarut-larut, 'Bunga' mulai mengalihkan minat seksualnya, TG bertutur, "Akhirnya dia mulai suka dengan sesama jenis. sejak dia ini SMP sudah mulai muncul seperti itu. nah sampai kuliah dia merasakan semakin kuat.. semakin kuat. babkan dia pernah bercerita memeluk teman kost-nya.. pada saat itu.. dan ketika direspon itu dia bahagia gitu lho.. si wanita tersebut.. akbirnya mereka menjalani bubungan-bubungan begitu. (TG/12-03-2016)." Sitatan ini menyiratkan bahwa 'Bunga' merasa bahagia saat memeluk teman wanitanya, dan direspon balik hingga mulailah terbentuk perilaku lesbi tersebut.

TG dalam proses pra-terapinya pun melakukan pendalaman analisis dan diagnosis, dan ditemukan terdapat beberapa faktor penyebab: Faktor Pelecehan Seksual: "Diagnosanya.. dia pernah mengalami pelecehan seksual pada saat kecil.. usia SD.. nah dia menikmati itu.. disitulah letak gangguannya.. Faktor Patah Hati: Dia pernah disakiti oleh pacarnya. Faktor Film Porno: Dia sering melihat filmfilm yang berbau ke seks. normal maupun tidak normal.. jadi ketika dia 'melihat wanita'.. itu dia terangsang.. Faktor Dosa dan Maksiat Orangtua: Bisa jadi orang tuanya itu melakukan sejumlah kemaksiatan-kemaksiatan. dibawa ke dalam bubungan suami-istri.. labirlah anaknya bisa autis.. bisa hiperaktif.. babkan bisa lesbi maupun homo.. banyak. data yang kami miliki.. Faktor Pengondisian Orangtua: Bisa juga lesbi atau homo itu muncul karena keinginan orang tua yang ingin mempunyai anak laki-laki tapi ternyata labir perempuan.. sehingga dia dikondisikan layaknya laki-laki. Faktor Mencela Takdir Allah: Dia itu mengatakan: 'kenapa Tuban mengizinkan saya seperti ini'.. itu yang sering muncul.. 'kenapa Tuban tidak membuat saya'.. nab itu kan berarti membuat dia salah faham dalam melihat sudut pandang takdirnya Allah.. Faktor Putus Asa Buruk Sangka Kepada Allah: Disinilah permainan 'syaithon'.. nah orang putus asa itu kan ujung-ujungnya buruk sangka.. orang buruk sangka itu ujung-ujungnya.. akbirnya 'tidak percaya dengan Allah'.." (TG/12-03-2016).

Dari sitatan-sitatan panjang di atas menyiratkan berbagai aspek yang dapat dicermati dalam melihat sejumlah masalah kasus korban homoseks (lesbi) pasien 'Bunga' berdasarkan pandangan TG yaitu: 
1. Berpikir perfeksionis, dalam artian segala keinginan itu mesti terwujud adalah penyebab timbulnya rasa frustasi bilamana yang terjadi justru sebaliknya;

2. Rasa frustasi adalah pemicu awal seseorang berperilaku menyimpang (malasuai);

3. Rasa frustasi 'Bunga' pun dialihkan dalam bentuk penjajakan objek seksual dengan sesama jenis kelamin.

4. Peristiwa traumatik di masa lalu, dalam hal ini 'Bunga' pernah mengalami pelecehan seksual di masa kanak-kanak yang justru dinikmatinya, dan itu berkontribusi dalam membentuk pikiran/keyakinannya;

5. Pengondisian orangtua mulai dari pra-kelahiran maupun pasca-kelahiran juga dapat berkontibusi membentuk pikiran/keyakinan bermasalah seseorang.

6. Dampak dari 'patah hati' dan rasa frustasi dalam menjalin hubungan pacaran yang mengecewakan;

7. Dampak dari maksiat pandangan (dan persepsi), dalam mana sering mengkomsumsi film porno; dan

8. Adalah yang paling riskan yaitu 'berburuk sangka, berputus asa, menolak, dan membenci takdir Allah' (kekufuran).

Dengan demikian, hasil temuan penelitian di atas sejalan menurut alGhazali (450-505 H) bahwa sebelum menetapkan tujuan dan menentukan teknik pengubahan perilaku, terlebih dahulu konselor (syekh) melakukan 'diagnosis' untuk mengetahui sebab, berat ringannya, dan jenis masalah konseli ${ }^{26}$. Dari sini dapat dipahami bahwa tradisi ulama Islam terdahulu dalam mana sebelum melakukan kegiatan terapiutik, maka diawali dengan upaya diagnosis masalah konseli terlebih dahulu.

Selanjutnya, pada dasarnya analisis dan diagnosis difokuskan pada pencermatan di aspek pandangan, pikiran/keyakinan, nafsu syahwat, dan perbuatan/kebiasaan. Pertama, pandangan adalah merupakan awal bermulanya problem pada pelaku seks bebas dan pelaku homoseks. Pandangan mata ditengarai sebagai medan perseptual. Mappiare-AT mengatakan bahwa persepsi menunjuk pada suatu kesadaran tunggal yang timbul dari proses pengindraan saat tampilnya suatu stimulus ${ }^{27}$. Kedua, pikiran/keyakinan, dibangun dengan terminologi 'cinta', sebagai temuan penelitian ini. Adapun kesyirikan dan kekufuran merupakan pikiran dan/atau keyakinan yang bermasalah dalam memaknai 'cinta', dan adalah 'penyakit cinta' lekat bagi korban homoseks. Dalam konsepsi REBT, pikiran/keyakinan yang bermasalah diberi terminologi irrational belief, dalam mana Mappiare menyatakan menunjuk pada sejumlah

\footnotetext{
${ }^{26}$ Sholeh. M., "Telaah Nilai-Nilai Ajaran Al-Ghazali Sebagai Satu Alternatif Pendekatan Konseling” (IKIP Malang, 1993).

${ }_{27}$ A. Mappiare-AT, Kamus Istilah Konseling \& Terapi (Jakarta: Raja Grafindo Persada, 2006).
} 
pemikiran atau keyakinan yang merugikan, yang penuh dengan pengharusan-diri sebagai petunjuk masalah pada konseli ${ }^{28}$.

Ketiga, nafsu syahwat, dalam mana ditengarai sebagai sex drive yang dinyatakan oleh Mappiare sebagai dorongan, kehendak, atau kebutuhan bersifat momentum untuk melakukan aktivitas seksual, ditimbulkan oleh desakan biologis $^{29}$. Keempat, perbuatan dan kebiasaan, dalam mana ditengarai sebagai behavior, dan Mappiare mengatakan bahwa behavior adalah suatu gerak kompleks yang dilakukan individu terhadap situasi tersedia, termasuk berpikir (covert behavior) di samping perilaku tampak (overt behavior) ${ }^{30}$. Sementara itu, kebiasaan ditengarai sebagai habits, dan Mappiare mengatakan bahwa habits adalah menunjuk pada sejumlah kebiasaan sebagai hasil belajar; dapat positif (dan dikehendaki masyarakat), dapat pula negatif (dan tidak dikehendaki masyarakat) ${ }^{31}$.

Atas keseluruhan uraian di atas, maka dapat disimpulkan bahwa prosesi pembentukan perilaku berkisar pada empat aspek utama, yaitu bermula (dimulai) dari persepsi, ke pikiran/keyakinan, ke sex drive, berujung pada behavior/habit. Dari hal ini, terlihat ekspektasi untuk mengkonstruk konsep mandiri. Persepsi dilabeli (P) tampak gayut dengan konsepsi gestalt. Pikiran/keyakinan dilabeli (K) tampak gayut dengan konsepsi Ellis. Sex drive dilabeli (S) tampak gayut dengan konsep perkembangan psikoseksual Freud. Adapun behavior dan habit dilabeli $(\mathrm{BH})$, tampak gayut dengan konsepsi Bandura. Selanjutnya meta-teori tersebut dianyam dalam satu konsep Psi-Ki-S-BH. Persepsi, keyakinan, sex drive, behavior, dan habit, disingkat dalam akronim bernama 'PsiKiS-BH'. Dengan demikian, pola-pola analisis dan diagnosis permasalahan pelaku seks bebas dan pelaku homoseks dikembangkan dari situ, diserap dari metode identifikasi masingmasing tokoh dan/atau pendekatan konseling di atas.

Pertama, persepsi dalam konsepsi Gestalt ialah berupaya mencermati perhatian dan minat terhadap sesuatu (figur dan latarnya), berkisar pada tiga zona kesadaran (outer, self, dan intermediate). Corey dalam hal ini menyatakan bahwa "The figure-formation process tracks how some aspect of the environmental field emerges from the background and becomes the focal point of the individual's attention and interest." ${ }^{\prime 2}$ Tampak bahwa konsep ini, dapat digunakan dalam melacak perhatian dan minat awal yang menyebabkan perilaku malasuai korban homoseks. Kedua, keyakinan dalam konsepsi Ellis ialah berupaya mencermati pikiran dan/atau keyakinan yang irasional, sebab inilah inti dari sasaran intervensi yang akan didispute. Berkenaan ini pula, Sharf mengatakan bahwa "The core approach to REBT is

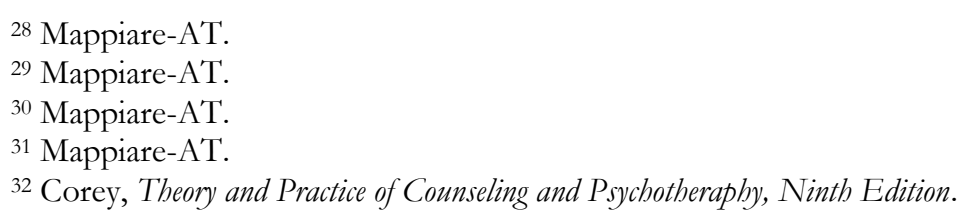


to dispute irrational thoughts; however, many other cognitive, emotive, and behavioral approaches are used to bring about change and meet clients' goals." 33 Tampak bahwa konsep ini, baik untuk menelusuri pikiran dan/atau keyakinan bermasalah korban homoseks.

Ketiga, sex drive dalam konsep 'perkembangan psikoseksual' Freud ialah mencermati proses pembentukan kepribadian dan/atau karakter seseorang di usia 0 sampai 5 atau 6 tahun awal perkembangan psikoseksual anak, khususnya di fase pragenital, Freud membaginya ke dalam tiga fase, yaitu oral, anal, dan falik $^{34}$. Intinya pelaku homoseks dapat dianalisis pada fase-fase tersebut. Freud mengatakan bahwa kelekatan bebas yang sama ke objek laki-laki dan perempuan seperti yang terlihat pada masa kanak-kanak membentuk dasar bagi terjadinya perkembangan seksual normal dan homoseksual atau sebaliknya (biseksual) ${ }^{35}$. Keempat, behavior dan habit dalam konsep Bandura ialah mencermati pola belajar observasional seseorang. Terdiri dari observasional learning atau belajar dengan melihat (mengamati), dan enactive learning atau belajar melakukan, dan banyak perilaku manusia dan keterampilan kognitif dipelajari dengan melihat model ${ }^{36}$. Dengan demikian, tampaknya, konselor dapat mengadopsi kaidah analisis dan diagnosis tersebut.

\section{Teknik Pengentasan Korban Homoseks}

Teknik ini terdiri dari dua jalur terapintik yang harus ditempuh, yaitu jalur pencegahan dan penyembuhan. Pertama, jalur pencegahan berupa 'berlatih diri' menundukkan pandangan dan penyibukan diri terhadap perkara-perkara maslahat. Kedua, jalur penyembuhan berupa penerapan teknik intervensi pikiran, muhasabah diri dan pernyataan tobat dan istigfar, serta terapi ibadah.

\section{Jalur Pencegahan}

Ibnu Qayyim al-Jauziyah bertutur bahwa "Upaya pencegahan faktorfaktor pendukung perilaku homoseks, yaitu jalan pencegahan dari timbulnya penyakit ini meliputi dua cara: (1) Menundukkan pandangan dari hal-hal yang diharamkan oleh-Nya untuk dipandang; (2) Yang dapat mencegah sampainya penyakit homoseks ke dalam jiwa adalah menyibukkan hati dengan perkaraperkara yang menjauhkan dan menghalanginya dari perbuatan tersebut, baik dengan rasa takut yang menggelisahkan maupun cinta yang mengganggu" $(\text { AWA } / \text { h.410) })^{37}$. Segayut dengannya, GL menyarankan pada pasien 'F' (korban

${ }^{33} \mathrm{R}$ Sharf, Theories of Psychotherapy and Counseling: Concepts and Cases, 5th Edition (USA: Brooks/Cole, 2012).

34 N. Jones, R., Teori Dan Praktik Konseling Dan Terapi, ed. S. M. (2011) Terjemahan Soetjipto, H. P. \& Soetjipto (Yogyakarta: Pustaka Pelajar, 2006).

35 Jones, $\mathrm{R}$.

36 Jones, $\mathrm{R}$.

37 Al-Jauziyah, Ad-Daa' Wa Ad-Dawaau'. 
homoseks) di luar sesi pertemuan terapiutiknya untuk mencari lingkungan yang sehat, dan kegiatan yang positif, dan bertutur: "Kita ajak dia untuk cari 'miliu'.. cari lingkungan yang bagus.. karna 'miliu' itu sangat kuat pengarubnya.. surub bijrah gitu.. terus harus punya kegiatan yang positif.. apalagi dia itu seorang mahasiswa yang kuliah di dua kampus gitu.."(GL/13-03-2016). Tampaknya, aksi hijrah adalah pilihan yang paling tepat bagi korban homoseks untuk sembuh.

Dalam upaya pencegahan perambatan penularan penyakit buruk homoseks, maka terdapat dua faktor yang perlu diperhatikan. Berkenaan dengan ini, dinyatakan pula oleh Ibnu Qayyim al-Jauziyah bahwa "Upaya pencegahan ini membutuhkan dua faktor yang jika seorang kehilangan keduanya atau salah satunya, maka dia tidak akan mendapat manfaat dari diri sendiri: (1) Pandangan yang benar agar dapat membedakan tingkatan-tingkatan cinta dan benci. Orang seperti ini akan mengedepankan perkara yang paling dicintainya daripada yang kurang dicintai. Ia juga bersabar atas perkara yang kurang dibenci agar terlepas dari perkara yang sangat dibencinya. Inilah keistimewaan akal. Seseorang tidak dianggap berakal jika bertindak sebaliknya; (2) Kekuatan tekad dan kesabaran untuk melakukan atau meninggalkan hal tersebut" (AWA/h.417) ${ }^{38}$.

Bila ditafsirkan secara ektensif pada konteks kekinian di masyarakat, maka hal-hal yang harus dilakukan oleh korban homoseks adalah:

1. Menundukkan pandangan terhadap hal-hal yang dilarang (diharamkan) dapat berupa perbuatan yang menghindarkan diri dari melihat film porno, fotofoto tak senonoh, memandang aurat sesama jenis kelamin, memandang dan mengagumi wajah sesama jenis kelamin, dan seterusnya. Intinya adalah semua itu dilakukan karena mengharap keridaan Allah.

2. Menyibukkan diri dengan perkara-perkara yang dapat mengalihkan imaji jahat berbuat homoseks, yaitu dengan perbuatan birrul walidain (berbakti kepada kedua orang tua), mengikuti pengajian/majelis taklim, membaca AlQur'an, membaca buku-buku Islami, menyimak ceramah para asatidæah di siaran tv Islami, bergaul dengan orang-orang saleh, aktif di organisasi dakwah, berolahraga (memacu kuda atau memanah) dan seterusnya. Seluruhnya dipandang dapat mengalihkan angan-angan (imaji) jahat berbuat homoseks. Tentunya, semua itu dilakukan karena mengharap keridhaan Allah.

3. Mengutamaan cinta dan benci terhadap sesuatu karena Allah, dalam mana korban homoseks belajar mengedepankan maslahat dan menolak berbagai mafsadat karena Allah.

4. Menguatkan tekad dan kesabaran, dalam mana korban homoseks belajar menjalankan segala perintah-Nya dan menjauhi segala larangan-Nya.

'Berlatih Diri' Menundukkan Pandangan Latihan keterampilan ini ialah 'berlatih diri' menundukkan pandangan mata secara kognitif, artinya mesti

38 Al-Jauziyah. 
dibarengi oleh pikiran/keyakinan bahwa perbuatan tersebut adalah wujud rasa cinta, harap, dan takut kepada Allah Ta'ala. Skills training methods dalam teori Ellis (REBT), gayut dengan hal tersebut, namun bedanya pada tataran materi bantahan keyakinan (belief), yang bersifat dogmatik. Tetapi tampak luwes, dengan dialog persuasif, dan 'butuh seni' dalam penyampaian nilai-nilai akidah dan tauhid, sebagaimana penuturan para subjek terteliti dalam temuan penelitian. Hal ini sebagaimana tuturan YD: "Cara-cara psikologi bisa diambil seperti... bagaimana kita membuat nyaman pasien. dan kata kuncinya. lancarnya komunikasi sama kejujuran pasien." (YD/08-03-2016).

Sebuah jurnal yang dipublikasikan oleh Carbone, nada-nadanya mengajak untuk melakukan 'latih diri' menundukkan pandangan dalam menangani masalah korban homoseks (gay), sebagaimana ungkapannya "the clinical treatment of four gay men for PTSD (Post-Traumatic Stress Disorder) using cognitive behavioral therapy (CBT) and eye movement desensitization and reprocessing (EMDR $)^{39}$." Dengan demikian 'berlatih diri' dan/atau terapi pandangan mata adalah merupakan sesuatu yang amat esensial bagi pelaku homoseks (gay).

Penyibukan Diri Terhadap Perkara-Perkara Maslahat $\sim$ Perkaraperkara yang dapat menyibukkan diri terhadap kemaslahatan dapat berupa kegiatan birrul walidain (berbakti kepada kedua orangtua), mengaji (baca AlQur'an), mengikuti pengajian/majelis taklim, membaca buku-buku Islami, menyimak ceramah asatidzah di tv Islami, bergaul dengan orang-orang sholeh, aktif di organisasi dakwah, berolahraga (memacu kuda dan memanah) dan seterusnya. Seluruh kegiatan tersebut bertujuan sebagai bentuk 'pengalihan', juga sebagai bentuk pembiasaan diri di lingkungan yang normal, sehat, dan memadai.

Nada-nadanya kegiatan-kegiatan di atas, gayut dengan 'teknik pengalihan' dalam pendekatan Beck. Dalam penggunaan teknik pengalihan, konseli di dorong untuk terlibat dalam kegiatan yang mengalihkan mereka dari emosi dan pikiran negatif yang dimilikinya ${ }^{40}$. Bergaul dengan orang saleh adalah salah satu bentuk pengalihan, dan Rahayu mengemukakan bahwa bergaul dengan orang saleh dapat dijadikan sebagai tempat berbagi rasa, pengetahuan dan berbagi pengalaman, serta nasihat-nasihat orang saleh akan dapat memberikan obat/terapi bagi kelainan atau penyakit mental seseorang ${ }^{41}$.

${ }^{39}$ Dominic J. Carbone, "Treatment of Gay Men for Post-Traumatic Stress Disorder Resulting from Social Ostracism and Ridicule: Cognitive Behavior Therapy and Eye Movement Desensitization and Reprocessing Approaches," Archives of Sexual Behavior 37, no. 2 (2008): 30516, https://doi.org/10.1007/s10508-007-9239-3.

${ }^{40}$ Jones, R., Teori Dan Praktik. Konseling Dan Terapi. Press, 2009).

${ }_{41}$ T Rahayu, I., Psikoterapi (Perspektif Islam \& Psikologi Kontemporer (Malang: UIN-Malang 


\section{Jalur Penyembuhan (Pengobatan)}

Ada tiga cara di jalur penyembuhan ini, yaitu penerapan teknik intervensi pikiran, muhasabah diri dan pernyataan tobat dan istigfar, serta terapi ibadah. Adapun bahasannya secara terperinci dan menstruktur disajikan sebagai berikut:

Penerapan Teknik Intervensi Pikiran Teknik ini terdiri dari 6 (enam) cara intervensi 'ajak berpikir' terhadap pribadi bermasalah. Intinya, korban homoseks diajak untuk mengajak mengenali diri sebagai hamba dan Allah sebagai Rabb-nya, mengajak mencintai Allah, mengajak merenungi masa, mengajak menemukan hikmah di balik musibah, dan mengajak mengkomparasi konsekuensi, serta mengajari cara menolak bisikan setan. Seluruhnya bertujuan untuk membangun kesadaran diri korban homoseks, alih-alih timbul rasa ingin bertobat.

\section{Mengajak Mengenali Diri dan Mengenali Allah}

Cara mengenali Allah dengan benar mesti meyakini dan mengucapkan bahwa seluruh nikmat yang melekat pada dirinya adalah berasal dari Allah, Ibnu Qoyyim al-Jauziyah berkata: "Orang yang mengenal siapa dirinya tidak akan mengatakan: 'Nikmat ini milikku', sebaliknya ia akan meyakini benar bahwa nikmat itu merupakan milik Allah, berasal dari Allah, dan hanya diberikan oleh Allah Ta'ala" (FF/h.497) ${ }^{42}$. Senada dengannya, AF juga bertutur, "Kalau pengen bahagia, niat kita ditujukan kepada Allah..kan gitu..'kenali dirimu lebih dabulu'.. itu kan ngajak berpikir. jadi kalau orang tabu babwasanya semua karunia dalam dirinya itu adalah datangnya dari Allah, maka orang tidak boleb sombong.. itu kan intervensi pikiran.." (AF/09-02-2016). Sitatan-sitatan tersebut pada intinya mengajak seseorang untuk mengetahui hakikat nikmat hidup, yang semuanya berasal dari pemberian Allah.

\section{Mengajak Mencintai Allah}

Setelah mengenali keberadaan diri sebagai seorang hamba dan Allah Ta'ala sebagai Tuhan (khalik), maka teknik selanjutnya adalah mengajak pribadi sakit, atau korban homoseks untuk dapat mencintai Allah Ta'ala, Ibnu Qoyyim Al-Jauziyah bertutur: "Yang paling mengherankan adalah Anda mengenal Allah, tetapi Anda tidak mencintai-Nya... termasuk dalam hal ini: Anda merasakan pahitnya kegelisahan karena maksiat kepada-Nya, tetapi Anda tidak mencari kedamaian hati dengan taat kepada-Nya.." (FF/h.501) ${ }^{43}$. Segayut dengannya, AF kembali bertutur: "Bagaimana..kita tidak mencintai Allab! nah itu..berbicara tentang. siapa orang yang bidup tidak butub. Allah, tidak bergantung pada Allah.padahal bahagia itu..ada di tangan Allah, semua kebutuhannya ditangan Allah, dirinya diciptakan oleb Allab; dan itu ngajak berpikir, ngajak emosi kita masuk untuk didalamnya.." (AF/09-

\footnotetext{
${ }^{42}$ Al-Jauziyah, Fawaa-Idul Fawaa-Id.

${ }^{43}$ Al-Jauziyah.
} 
02-2016). Pada intinya, sitatan tersebut mengajarkan bahwa mencintai Allah adalah suatu kebutuhan hakiki manusia.

\section{Mengajak Merenungi Masa}

Setelah mengajak mencintai Allah, maka korban homoseks diajak merenungi masa, membayangkan kepedihan akhirat akan menghampiri tatkala seorang hamba tetap mengisi hari-harinya dengan kelalaian, dan memperturutkan hawa nafsu dan syahwatnya, Ibnu Qoyyim Al-Jauziyah berucap: "Sesungguhnya, menjaga waktu yang sekarang dijalani lebih sulit daripada memperbaiki waktu yang telah berlalu maupun waktu yang akan datang. Pasalnya, menjaga waktu berarti mengharuskan diri Anda melakukan sesuatu yang lebih baik, lebih bermanfaat, dan lebih banyak memberikan kebahagiaan bagi diri Anda" (FF/h.470) ${ }^{44}$; "Jika Anda mengutamakan nafsu syahwat, kesenangan, kelalaian, dan permainan, maka waktu itu akan cepat sekali berlalu meninggalkan Anda. Bahkan, kesudahannya berdampak kepedihan yang sangat abadi" (FF/h.471) ${ }^{45}$. Berkaitan dengannya, AF juga bertutur: "Supaya orang itu berubah jadi baik, bagi yang sudab lewat, yang kurang..dia istigfar-i, kalau ada kesalahan, dia ambil pelajaran; trus yang akan datang.cukup tidak perlu melakukan yang salab; trus yang saat ini.jangan buat maksiat..dosa.. sehingga kalau bidup ini kita bisa jaga terus. kita akan masuk surga dengan mudah banget.. ini kan menggerakean emosi untuk. bangkit, ternyata masuk surga itu tidak sulit..cukup hari ini lakukan evaluasi.." (AF/0902-2016). Implikasi dari sitatan tersebut bermuara pada komitmen tobat dan istigfar korban homoseks atas masa lalunya, tidak mengulanginya di masa sekarang dan menjadi pribadi yang lebih baik di masa mendatang.

\section{Mengajak Menemukan Hikmah di Balik Musibah}

Perkara cinta dan benci adalah fitrah bagi manusia, namun perlu dicermati bahwa ada hal-hal yang dicintai oleh manusia kerapkali tidak disukai oleh Allah, dan begitu pun sebaliknya: "Kemaslahatan jiwa umumnya terdapat pada segala hal yang dibencinya, sebagaimana kemudharatan dan sebab-sebab kehancuran jiwa biasanya terkandung pada segala hal yang dicintainya (FF/h.245) ${ }^{46}$."

Analogi Hikmah di Balik Musibah Analogi perlakuan kasih-sayang, ayah kepada anaknya: Seperti itu pula perlakuan seorang ayah yang mengasibi anak kandungnya dan mengira benar akan kemaslahatan anaknya tersebut. Jika si ayah mengetabui babwa kemaslahatan anaknya hanya bisa diraib dengan cara hijamah, yaitu mengeluarkan darab kotor yang ada pada tububnya, maka ia pasti akan rela mengiris kulit anaknya dan membuka jalan darabnya agar mengalir keluar, meskipun anak itu akan merasa sakit. Begitu juga, jika si ayah melihat bahwa sebagian anggota tubuh anaknya harus diamputasi demi kesembuhannya, niscaya ia akan

\footnotetext{
${ }^{44}$ Al-Jauziyah.

45 Al-Jauziyah.

46 Al-Jauziyah.
} 
memotong bagian tubuh tersebut. Semua itu ia lakukan karena kasih sayangnya kepada si buah hati (FF/h.246) ${ }^{47}$. Sitatan-sitatan di atas mengarahkan korban homoseks untuk berpikir lebih dewasa dan bijak dalam memaknai ujian Allah yang sedang dijalaninya, untuk kemudian sadar bahwa Allah sayang padanya.

\section{Mengajak Mengkomparasi Konsekuensi}

Setelah korban homoseks mulai menimbulkan rasa cinta kepada Allah Ta'ala, kemudian timbul rasa ingin bertobat, maka cara selanjutnya adalah dia diajak untuk membuat perbandingan dari konsekuensi antara ketaatan dan kemaksiatan terhadap perintah Allah.

Kesenangan yang dirasakan saat melakukan kemaksiatan akan berdampak pada kepedihan di akhirat: "Kesenangan yang diharamkan itu bercampur dengan keburukan ketika menikmatinya, dan pasti membuabkan kepedihan di akbirat. Oleb sebab itu, apabila muncul dorongan yang sangat hebat untuk melakukan kesenangan yang diharamkan, maka pikirkanlah terlebih dahulu bahwa kesenangan yang diharamkan itu pasti akan bilang; sedangkan keburukan dan kepediban yang diakibatkannya akan kekal selama-lamanya. Kemudian, bandingkanlah kedua perkara tersebut, lalu perhatikanlah perbedaan antara keduanya (FF/h.606) ${ }^{48}$."

Sebaliknya keletihan yang dirasakan saat melakukan ketaatan, nanti akan berdampak pada kebaikan di akhirat: "Keletihan dalam mengerjakan ketaatan bercampur dengan kebaikan, dan pasti membuabkean kesenangan dan kenyamanan setelah melakukannya. Apabila dorongan untuk melakukan ketaatan dirasakan jiwa, maka renungkanlah bahwa keletihannya pasti akan bilang; sedangkan kebaikan, kelezatan, dan kebahagiaan yang dihasilkannya akan kekal selama-lamanya. Bandingkanlah kedua hal itu, kemudian utamakanlah yang lebih kuat dampaknya, dan tinggalkanlah yang tidak kuat (FF/h.606)" ${ }^{49}$." Sitatan-sitatan ini pada intinya bertujuan untuk menguatkan kesadaran diri korban homoseks dalam kekonsistenan untuk merubah perilakunya.

\section{Mengajari Cara Menolak Bisikan Setan}

Teknik intervensi pikiran ini bertujuan untuk mengontrol, mengendalikan, dan menolak bisikan jiwa atau lintasan-lintasan pikiran jahat di dalam diri pelaku seks bebas dan homoseks. Ibnu Qayyim Al-Jauziyah mengatakan bahwa: "Ketahuilah, bahwasanya apa-apa yang terlintas dalam jiwa itu tidaklah membahayakan. Yang membahayakan adalah memanggil lintasan tersebut dan berbincang-bincang dengannya. Apa yang terlintas dalam benak itu seperti seseorang yang berlalu, yang jika dibiarkan dan tidak dipanggil, pasti dia akan berpaling darimu. Sebaliknya, jika kau panggil, niscaya dia akan menyihirmu

\footnotetext{
47 al-Jauziyah.

48 al-Jauziyah.

49 al-Jauziyah.
} 
dengan ucapan dan tipu daya. Perkara ini sangat sepele bagi jiwa yang kosong lagi bathil, tetapi merupakan perkara besar bagi hati dan jiwa yang mulia, tinggi, serta tentram" (AWA/h.358) $)^{50}$. Ihwal cara menolak bisikan setan, ZW dalam terapinya terhadap korban homoseks bertutur: "Untuk nonton dan onani disurub putus.. trus usabakan kalo man ngumpul 'ada bisikan'..merasa malu..'disurub berdoa'.. 'surub lawan'.. 'mainnya di pikiran'.. 'kamu bukan saya'..kalo muncul rasa malu..langsung ditembak aja..'sugesti'.. 'Kamu bukan saya'..” (ZW/08-03-2016). Sitatansitatan tersebut adalah upaya untuk mengajari korban homoseks dalam berlatih menolak lintasan-lintasan pikiran jahat di hati dan pikirannya.

Muhasabah Diri dan Pernyataan Tobat dan Istigfar Penerapan muhasabah diri lebih ditekankan pada prosesi mengingat-ingat anggota badan mana saja yang telah berbuat dosa. Mata, telinga, mulut, hidung, tangan, kaki, dan kemaluan adalah anggota badan yang rentan berlaku dosa pada diri korban homoseks. Muhasabah diri dimaksudkan untuk mengevaluasi seluruh perbuatan anggota badan secara spesifik: "Mata, telinga, mulut, kemaluan, tangan, dan kaki; semuanya merupakan kendaraan yang mengantarkan kepada kebinasaan maupun keselamatan.. (IL/h.123) ${ }^{51}$; Apabila seseorang telah menyadari kekurangan dirinya, ia harus segera melakukan evaluasi... (IL/h.124) ${ }^{52}$."

Berangkat dari nuhasabah diri, maka satu persatu anggota badan yang melakukan dosa tersebut, dievaluasi, ditobati dan dimintakan ampun kepada Allah: "Dinamakan tobat apabila seseorang telah tahu akan dosanya, mau mengakuinya, serta memohon agar dibindarkan dari akibat buruk perbuatan dosanya (AWI/h.25) Pengarub dosa dan maksiat dalam hati, maka obatnya hanyalah taubat dan istighfar $(\mathrm{ZD} / \text { h.262 })^{54}$; Dan pintu kejahatan akan ditutup melalui tobat dan istigfar $(\mathrm{ZD} / \mathrm{h} .254)^{55}$; Memohon ampunan (istighfar) memiliki pengarub yang luar biasa untuk menghilangkan penderitaan, kesediban dan kesempitan hati (TN/h.152)."

Berkenaan cara-cara tersebut, gayut dengan teknik imagery dalam pendekatan Beck. Sementara menurut Ma'aruf melalui hasil kajiannya menginterpretasi muhasabah sebagai teknik self-observation, teknik self-evaluation, dan self-analysis, dalam mana seseorang dapat memahami dan mengenali masalahnya ${ }^{57}$. Pernyataan tobat dan istigfar, titik penekanannya pada prosesi

${ }^{50}$ Al-Jauziyah, Ad-Daa' Wa Ad-Dawaau'.

${ }^{51}$ I.Q. Al-Jauziyah, Ighatsatul Lahfan, ed. H. Terjemahan Sayyid, A \& Murtadho (Solo: AlQowam, 2014).

${ }^{52}$ Al-Jauziyah.

53 I.Q. Al-Jauziyah, At-Taubah Wa Al-Inabah, ed. Terjemahan Dzulfikar (Jakarta: Qisthi Press, 2012).

${ }^{54}$ I.Q. Al-Jauziyah, Zadul Ma’ad, ed. A. Terjemahan Djalil (Jakarta: Griya Ilmu, 2013).

55 Al-Jauziyah.

56 Al-Jauziyah, Thibbun Nabawi.

${ }^{57}$ H. Ma'aruf, "Landasan Konseling Berwawasan Islam Ditinjau Dari Filsafat Eksistensial Humanis” (UM Malang, 2001). 
pernyataan pengakuan kesalahan, penyesalan, dan bertekad untuk tidak mengulangi perbuatan homoseksnya. Selanjutnya diteruskan dengan memohon ampunan kepada Allah atas dosa yang telah diperbuatnya tersebut. Cara-cara tersebut, gayut dengan teknik role reversal dan teknik repeating rational self-statements, yang digunakan dalam pendekatan Ellis (REBT). Adapun Ma'aruf melalui hasil kajiannya mengemukakan bahwa pertobatan gayut dengan teknik catharsis dan abreaction, dalam mana konseli mengungkapkan kepada konselor perasaanperasaan bersalah atau berdosanya, sedangkan konselor dengan bijak mampu mendengarkan, memperhatikan, memahami, dan menerima ungkapan perasaan konseli tersebut ${ }^{58}$.

Dengan demikian, dari paparan di atas, maka dapat disimpulkan bahwa muhasabah lebih mengarah pada eksplorasi domain kognitif, sementara tobat dan istigfar lebih mengarah pada eksplorasi afektif. Kedua-duanya saling berkinerja dan berdinamika dalam operasi penyelesaian masalah korban homoseks.

Terapi ibadah Praktik ibadah adalah suatu prosesi penyembuhan penyakit homoseks, mengobati, memulihkan, memelihara, dan meningkatkan kesehatan mental pelaku homoseks. Selain itu, juga dapat mencegah pengaruhpengaruh buruk yang dapat melahirkan perilaku homoseks. Adapun bentukbentuk teknik terapi ibadah dapat berupa; doa, zikir pagi-petang, puasa, salat, sedekah/zakat, tadabbur Al-Qur'an, i'tikaf, ruqyah Ilahiah, dan lainnya. Berikut secara runut ditampilkan hasil interpretasi atas teks pemikiran Ibnu Qayyim AlJauziyah:

Doa Mustajabah Doa merupakan praktik ibadah yang melibatkan pelepasan emosi. Semisal perasaan takut, cemas, dan harap berdinamika saat seseorang memohon ampunan kepada Allah ta'ala atas dosa-dosanya, dan mengutarakan hajat kepada-Nya. Doa semakin cepat diijabah oleh Allah Ta'ala, manakala seseorang perhatian terhadap adab-adab, tempat, situasi-kondisi, dan waktu-waktu terijabahnya sebuah doa ${ }^{59}$. Adapun manfaat dari berdoa diyakini dapat mencegah dan mengatasi penyakit hati (psikis), sebagaimana korban homoseks. Selain itu, diyakini pula dapat meningkatkan kesehatan mental.

Zikir Pagi-Petang Zikir pagi-petang merupakan praktik ibadah berupa pengulang-ulangan ucapan berupa doa (permohonan/permintaan) atau hajat kepada Allah Ta'ala ${ }^{60}$, secara khusus di lakukan pada setiap pagi dan petang. Dapat dilakukan saat duduk, berdiri/berjalan, berbaring, berkendaraan, dan dalam perjalanan (safar). Adapun manfaat dari zikir pagi-petang diyakini dapat mencegah dan mengatasi penyakit hati (psikis) korban homoseks. Selain itu,

${ }^{58}$ Ma'aruf.

${ }^{59}$ Al-Jauziyah, Ad-Daa' Wa Ad-Dawaau'.

${ }^{60}$ I.Q. Al-Jauziyah, Mukhtashar Al-Wabil Ash-Shayyib Wa Rafi' Al-Kalim Ath-Thayyib, ed. S. A. Terjemahan Sayyid (Solo: Pustaka Arafah, 2011). 
diyakini pula dapat meningkatkan kesehatan mental. Ihwal doa dan zikir, Prayitno menyebutkan bahwa beberapa hasil penelitian telah menampilkan bukti konkret bahwa kegiatan berdoa, berdizkir dan amalan ibadah harian dapat menurunkan gejala-gejala depresi yang dialami oleh seseorang ${ }^{61}$.

Puasa Puasa merupakan praktik ibadah berupa pengontrolan diri/kontrol diri, dari nafsu-syahwat (kemaluan) dan nafsu-amarah (kemarahan), tentunya makan dan minum, pandangan mata, pendengaran, ucapan lisan, langkah kaki, dan anggota badan lainnya ${ }^{62}$. Semua kegiatan kontrol diri tersebut dilakukan atas dasar cinta kepada Allah ta'ala. Adapun manfaat dari berpuasa diyakini dapat mencegah dan mengatasi penyakit hati (psikis) korban homoseks. Selain itu, dapat pula meningkatkan kesehatan mental alih-alih kesehatan fisik. Aqiilah mengimbuhkan bahwa puasa dapat berimplikasi pada kebahagiaan, kontrol diri, spiritualitas, religiusitas, emosi positif, regulasi emosi, perilaku prososial, interaksi sosial, relasi sosial, serta agresivitas ${ }^{63}$.

Salat Salat merupakan praktik ibadah yang terdiri dari ucapan dan gerakan. Seluruh ucapan dan gerakan tersebut bermakna doa (permohonan/permintaan) ampunan, pertolongan, dan hajat kepada Allah $\mathrm{Ta}^{\prime} \mathrm{ala}^{64}$. Adapun manfaat dari shalat ialah diyakini dapat mencegah dan mengatasi penyakit hati (psikis), sebagaimana korban homoseks. Selain daripada itu, diyakini pula dapat meningkatkan kesehatan mental alih-alih kesehatan fisik. Dengan demikian, salat dapat dijadikan sebagai sarana terapiutik, sebagaimana Al Baqi dan Sholihah menyatakan bahwa salat dapat memberikan implikasi psikologis bagi muslim yang melaksanakannya, di antaranya meringankan stres, meningkatkan kepekaan interpersonal, meningkatkan subjective well-being, dan lain sebagainya ${ }^{65}$.

Sedekah/zakat Sedekah atau zakat merupakan praktik ibadah yang umumnya berupa pengeluaran harta seseorang kepada orang lain (yang membutuhkan), butuh pengorbanan, dan berani mengambil resiko ${ }^{66}$. Semua itu dilakukan atas dasar cinta kepada Allah Ta'ala. Adapun manfaat dari sedekah/zakat ialah diyakini dapat mencegah bala' (musibah), mengatasi penyakit hati (psikis) korban homoseks. Selain itu, dapat pula meningkatkan

${ }^{61}$ H Prayitno, S., "Doa Dan Dzikir Sebagai Metode Menurunkan Depresi Penderita Dengan Penyakit Kronis," Seminar Psikologi \& Kemanusiaan, 2015, 354-58.

62 Al-Jauziyah, Ad-Daa' Wa Ad-Dawaau'.

${ }^{63}$ I Aqiilah, I., "Puasa Yang Menajubkan (Studi Fenomenologis Pengalaman Individu Yang Menjalankan Puasa Daud)," Empati 9, no. 2 (2020): 82-108.

${ }^{64}$ I.Q. Al-Jauziyah, Asrar Al-Shalat, ed. G. Terjemahan Laily, A. \& Hasan (Jakarta: Penerbit Zaman, 2013).

${ }^{65} \mathrm{Al}$ Baqi, S. and M Sholihah, A., "Manfaat Shalat Untuk Kesehatan Mental: Sebuah Pendekatan Psikoreligi Terhadap Pasien Muslim," QALAMUNA: Jurnal Pendidikan, Sosial, Dan Agama 11, no. 1 (2019): 83-92, https://doi.org/https://doi.org/10.5281/zenodo.3559226.

${ }^{66}$ Al-Jauziyah, Zadul Ma'ad. 
kesehatan mental alih-alih ketenangan batin. Nurjannah menambahkan bahwa aksi sedekah/zakat seseorang lahir dari spirit positif yang berdinamika secara psikologis spiritual, yang mana spirit ruh tauhid itu melahirkan kecerdasan spiritual, moral, sosial dan emosional dalam berderma, serta melawan suara nafsu setan dan mengelola suara kebenaran ${ }^{67}$.

Tadabbur al-Qur'an Tadabbur al-Qur'an merupakan praktik ibadah berupa kegiatan membaca, mempelajari, dan merenungi isi kandungan alQur'an $^{68}$. Berkonsentrasi diri dan memosisikan diri sebagai seorang hamba yang diajak bicara oleh Allah Ta'ala saat membaca al-Qur'an adalah hal ditekankan (utama). Adapun manfaat dari ber-tadabbur al-Qur'an ialah diyakini dapat mengatasi penyakit hati (psikis) korban homoseks. Selain itu, dapat pula meningkatkan kesehatan mental. Senada dengannya, melalui hasil penelitian Mar'ati dan Chaer menunjukkan bahwa tadabbur al-Qur'an atau pembacaan dan pemaknaan ayat-ayat al-Qur'an terbukti mampu menurunkan tingkat kecemasan santriwati Aliyah Pondok Pesantren Ar Rohmah Ngawi ${ }^{69}$.

Iktikaf Iktikaf merupakan praktik ibadah berupa kegiatan menyendiri atau bersengaja mengasingkan diri dari kepenatan rutinitas duniawi di Masjid ${ }^{70}$. Bertujuan untuk fokus berzikir kepada Allah Ta'ala semata. Adapun manfaat dari i'tikaf ialah diyakini kuat dapat mengatasi penyakit hati (psikis) korban homoseks. Selain itu, dapat pula meningkatkan kesehatan mental. Segayut dengannya, Karakaş dan Eker melalui hasil penelitiannya menunjukkan bahwa iktikaf terbukti mampu menurunkan emosi (kemarahan), sekaligus meningkatkan Subjective Well-Being seseorang ${ }^{71}$.

Ruqyah Ilahiah Ruqviah Ilabiah merupakan praktik ibadah berupa kegiatan membaca doa, dan surah-surah (ayat-ayat) al-Qur'an, dan meniupkan hembusan napas di air (semisal dalam gelas) ${ }^{72}$. Bertujuan sebagai terapi yang diyakini kuat sebagai wasilah/sarana penyembuh terhadap penyakit hati (psikis). Keterpaduan/sinergitas antara ketaatan (dan keshalehan) perukiah (roqy) dengan kesiapan diri berobat (dan bertobat) orang yang dirukiah (marqy) adalah merupakan potensi 'enerji spiritual' yang berpengaruh positif pada prosesi rukiah

${ }^{67}$ N. Nurjannah, "Psikologi Spiritual Zakat Dan Sedekah,” Istinbath 17, no. 1 (2018): 179-97.

${ }^{68}$ Al-Jauziyah, Fawaa-Idul Fawaa-Id.

${ }^{69} \mathrm{R}$ Mar'ati and T Chaer, M., "Pengaruh Pembacaan Dan Pemaknaan Ayat-Ayat AlQur'an Terhadap Penurunan Kecemasan Pada Santriwati," Psikobumaniora: Jurnal Penelitian Psikologi 1, no. 1 (2016): 300-348, https://doi.org/10.21580/pipp.v1i1.966.

${ }^{70}$ Al-Jauziyah, At-Taubah Wa Al-Inabah.

${ }^{71} \mathrm{C}$ Karakaş, A. and H Eker, H., "The Effects of Itikaf on State-Trait Anger, Intrinsic Religiousness, and Subjective Well-Being," Spiritual Psychology and Counseling 3, no. 2 (2018): 161 76, https://doi.org/10.37898/spc.2018.3.2.0044.

${ }^{72}$ Al-Jauziyah, Thibbun Nabawi. 
Ilahiah. Adapun manfaat dari ruqyah Ilahiah ialah diyakini dapat mengatasi penyakit hati (psikis), korban homoseks.

Hal ini sejalan dengan penelitian oleh Perdana Akhmad yang menyatakan bahwa rukiah dapat menyembuhkan penyakit mental, dan agar prosesnya berjalan efektif, maka diperlukan serangkaian tahapan, yaitu: (1) persiapan sebelum psikoterapi rukiah; (2) pelaksanaan psikoterapi rukiah, yang terdiri atas aktivitas mendengarkan lantunan ayat suci al-Qur'an dengan khusyuk dan adanya sensasi yang terjadi selama prosesi mendengarkan lantunan ayat suci al-Qur'an; (3) pelaksanaan konseling dan rukiah pada diri pasien secara pribadi ${ }^{73}$.

\section{Penutup}

Ada empat strategi terapiutik terhadap korban homoseks. Di antaranya: pertama, fokus utama pengintervensian, berfokus pada intervensi pikiran/keyakinan; kedua, target menuju pribadi sehat, pengalihan dari pribadi yang senang berbuat dosa dan maksiat menuju pribadi yang taat kepada perintah Allah dan menjauhi larangan-Nya. Secara khusus, pribadi sehat adalah pribadi yang bertauhid, berilmu, berzikir (mengingat Allah), bertaubat, ikhlas, jujur, tegar (asertif), tunduk pada ketentuan Allah, tawaduk, dan senang beramal saleh. Keseluruhan ciri pribadi sehat tersebut, sudah tentu dipandang sebagai tujuan dari diadakannya intervensi pengubahan perilaku kepada korban homoseks. Ketiga, analisis dan diagnosis, upaya mengidentifikasi dan menemukan kesalahan dalam rantai persepsi, keyakinan, sex drive, behavior, dan babit korban homoseks. Keempat, penerapan teknik pengentasan korban homoseks terdiri dari jalur pencegahan dan penyembuhan, jalur pencegahan berupa 'latih diri' menundukkan pandangan dan menyibukkan diri dengan perkara-perkara yang maslahat, sementara jalur penyembuhan berupa penerapan teknik intervensi pikiran, muhasabah diri dan pernyataan tobat dan istigfar, dan terapi ibadah.

Adapun terapi ibadah meliputi doa mustajabah, zikir pagi-petang, puasa, salat, sedekah/zakat, tadabbur al-Qur'an, iktikaf, dan rukiah ilahiah. Rekomendasi dari penelitian ini diharapkan dapat diterapkan oleh praktisi helping profession dan konselor di sekolah atau madrasah dalam pemberian layanan konseling terhadap korban homoseks.

\section{Daftar Pustaka}

Akhmad, P. "Terapi Ruqyah Sebagai Sarana Mengobati Orang Yang Tidak Sehat Mental.” Jurnal Psikologi Islam 1, no. 1 (2017): 87-96.

Al-Jauziyah, I.Q. Ad-Daa' Wa Ad-Dawaau'. Edited by A Terjemahan Kurniawan.

${ }^{73}$ P Akhmad, "Terapi Ruqyah Sebagai Sarana Mengobati Orang Yang Tidak Sehat Mental," Jurnal Psikologi Islam 1, no. 1 (2017): 87-96. 
Jakarta. Pustaka Imam Asy-Syafi'i, 2009.

Ar-Rub Li Ibnul Qayyim. Edited by Terjemahan Suhardi. Jakarta: Pustaka Al-Kautsar, 2012.

- Asrar Al-Shalat. Edited by G. Terjemahan Laily, A. \& Hasan. Jakarta: Penerbit Zaman, 2013.

- At-Taubab Wa Al-Inabah. Edited by Terjemahan Dzulfikar. Jakarta: Qisthi Press, 2012.

- Fawaa-Idul Fawaa-Id. Edited by S Terjemahan Djamaluddin. Jakarta: Pustaka Imam Asy-Syafi'i, 2012.

. Ighatsatul Labfan. Edited by H. Terjemahan Sayyid, A \& Murtadho. Solo: Al-Qowam, 2014.

Mukhtashar Al-Wabil Ash-Shayyib Wa Rafi' Al-Kalim Ath-Thayyib. Edited by S. A. Terjemahan Sayyid. Solo: Pustaka Arafah, 2011.

. Tbibbun Nabawi. Edited by A. U. B. Terjemahan Al-Maidani. Bandung: Penerbit Jabal Pustaka, 2015.

—. Zadul Ma'ad. Edited by A. Terjemahan Djalil. Jakarta: Griya Ilmu, 2013.

Alamsyah, Agung, Hasbiyallah Hasbiyallah, and Nanat Fatah Natsir. "Pendidikan Agama Islam Dalam Mengatasi Perilaku Homoseksual (Gay)." Risâlah, Jurnal Pendidikan Dan Studi Islam 6, no. 1 (October 15, 2019): 139_ 149. https://doi.org/10.31943/jurnal_risalah.v6i1.117.

Alvesson, M., and K. Sköldberg. Reflexive Methodology: New Vistas for Qualitative Research. Sage, 2017.

Aqiilah, I., I. "Puasa Yang Menajubkan (Studi Fenomenologis Pengalaman Individu Yang Menjalankan Puasa Daud).” Empati 9, no. 2 (2020): 82-108.

Arus Pelangi. “Arus Pelangi,” 2020. http://www.aruspelangi.or.id/.

Baqi, S., Al, and M Sholihah, A. "Manfaat Shalat Untuk Kesehatan Mental: Sebuah Pendekatan Psikoreligi Terhadap Pasien Muslim." QALAMUNA: Jurnal Pendidikan, Sosial, Dan Agama 11, no. 1 (2019): 83-92. https://doi.org/https://doi.org/10.5281/zenodo.3559226.

Carbone, Dominic J. "Treatment of Gay Men for Post-Traumatic Stress Disorder Resulting from Social Ostracism and Ridicule: Cognitive Behavior Therapy and Eye Movement Desensitization and Reprocessing Approaches." Archives of Sexual Behavior 37, no. 2 (2008): 305-16. https://doi.org/10.1007/s10508-007-9239-3.

Corey, G. Theory and Practice of Counseling and Psychotheraphy, Ninth Edition. USA: Thomson Brooks/Cole, 2013. 
Dryden, W. Understanding Psychological Health: The REBT Perspective. USA: Routledge, 2011.

Ellis, A, and W Dryden. The Practice of Rational Emotive Behavior Therapy. New York: Springer Publishing Company, Inc, 2007.

Fathuddin, M., H, and R Amir, F. "Konsep Tazkiyatun Nafs Menurut Ibnu Qoyyim Al Jauziyah Dalam Kitab Madarijus Shalikin Serta Implikasinya Terhadap Pendidikan." TADBIR MUW AHHID 5, no. 2 (2016): 117-27. https://doi.org/http://dx.doi.org/10.30997/jtm.v5i2.332.

Giri, A., M, A Bajari, and E Maryani. "LGBT Di Era Digital: Eksistensi Dan Kontroversi." In Book Chapter: Communication \& Information Beyond Boundaries, 93-100. Bandung: Seminar Nasional MACOM III Universitas Padjadjaran 2019, 2019.

Hasnah, H, and S Alang. "Lesbian, Gay, Biseksual Dan Transgender (Lgbt) Versus Kesehata: Studi Etnografi." Jurnal Kesehatan 12, no. 1 (2019): 63-72. https://doi.org/10.24252/kesehatan.v12i1.9219.

Institute, The SMERU Research. "Arus Pelangi," 2020. http://smeru.or.id/id/content/arus-pelangi\#: :text=Arus Pelangi adalah sebuah organisasi,LGBT) sebagai hak asasi manusia.

Jones, R., N. Teori Dan Praktik Konseling Dan Terapi. Edited by S. M. (2011) Terjemahan Soetjipto, H. P. \& Soetjipto. Yogyakarta: Pustaka Pelajar, 2006.

Karakaş, A., C, and H Eker, H. "The Effects of Itikaf on State-Trait Anger, Intrinsic Religiousness, and Subjective Well-Being." Spiritual Psychology and $\begin{array}{lllll}\text { Counseling } 3, & \text { no. } 2018): & 2 & 161-76 .\end{array}$ https://doi.org/10.37898/spc.2018.3.2.0044.

Khairani, A, and D Saefudin. "Homoseksual Berdasarkan Pandangan Psikologi Islam." Ta'dibuna: Jurnal Pendidikan Islam 7, no. 2 (2018): 114-36. https://doi.org/10.32832/tadibuna.v7i2.1356.

Ma'aruf, H. "Landasan Konseling Berwawasan Islam Ditinjau Dari Filsafat Eksistensial Humanis." UM Malang, 2001.

Mansur, S. "Homoseksual Dalam Perspektif Agama-Agama Di Indonesia." Aqlania $8, \quad$ no. 1 (2017): https://doi.org/http://dx.doi.org/10.32678/aqlania.v8i01.1020.

Mappiare-AT, A. Kamus Istilah Konseling \& Terapi. Jakarta: Raja Grafindo Persada, 2006.

Mappiare-AT, Andi. Dasar-Dasar Metodologi Riset Kualitatif Untuk Ilmu Sosial Dan Profesi. Malang: Jenggala Pustaka Utama Bersama Fakultas Ilmu Pendidikan Universitas Negeri Malang, 2009. 
. "Tipe-Tipe Metode Riset Kualitatif Untuk Eksplanasi Sosial Budaya Dan Bimbingan Konseling." Malang: Elang Mas bersama Prodi Bimbingan dan Konseling Fakultas Ilmu Pendidikan Universitas Negeri Malang, 2013.

Mar'ati, R, and T Chaer, M. "Pengaruh Pembacaan Dan Pemaknaan Ayat-Ayat Al-Qur'an Terhadap Penurunan Kecemasan Pada Santriwati." Psikobumaniora: Jurnal Penelitian Psikologi 1, no. 1 (2016): 300-348. https://doi.org/10.21580/pjpp.v1i1.966.

Nugrohowati, Nunuk, Ria Maria Theresa, Inas Hanuniza, and Ranti K Dewi. "Factors Associated with Risky Behavior for HIV/AIDS Transmission Among Youth Organization in Depok, West Java." In Proceedings of the 4th International Symposium on Health Research (ISHR 2019), 22:648-54. Paris, France: Atlantis Press, 2020. https://doi.org/10.2991/ahsr.k.200215.127.

Nurjannah, N. "Psikologi Spiritual Zakat Dan Sedekah." Istinbath 17, no. 1 (2018): 179-97.

Prayitno, S., H. "Doa Dan Dzikir Sebagai Metode Menurunkan Depresi Penderita Dengan Penyakit Kronis." Seminar Psikologi \& Kemanusiaan, 2015, 354-58.

Rahayu, I., T. Psikoterapi (Perspektif Islam \& Psikologi Kontemporer. Malang: UINMalang Press, 2009.

Riswanto, Dody, and Aswar Aswar. "Prosedur Konseling Rational Emotive Behavior Dalam Penanganan Pelaku LGBT." Advice: Jurnal Bimbingan Dan Konseling 2, no. 1 (June 15, 2020): 12-27. https://doi.org/10.32585/advice.v2i1.682.

Rosyidah, S., K. "Pengaruh Globalisasi Dalam Perkembangan Perjuangan Identitas Dan Hak Kelompok LGBT Di Indonesia." Global Dan Policy 5, no. 2 (2017): 183-98. http://ejournal.upnjatim.ac.id/index.php/jgp/article/view/1892.

Sharf, R. Theories of Psychotherapy and Counseling: Concepts and Cases, 5th Edition. USA: Brooks/Cole, 2012.

Sholeh. M. "Telaah Nilai-Nilai Ajaran Al-Ghazali Sebagai Satu Alternatif Pendekatan Konseling.” IKIP Malang, 1993. 
154 | Islamic Counseling: Jurnal Bimbingan dan Konseling Islam, Vol. 4, No. 2, 2020 